\title{
Pola Asuh Orang Tua Terhadap Motivasi Belajar Siswa SMP Unggulan 'Aisyiyah Bantul
}

\author{
Saibah $^{1}$, Wantini ${ }^{1}$ \\ ${ }^{1}$ Universitas Ahmad Dahlan, Yogyakarta \\ *Corresponding email: saibah1907052001@ webmail.uad.ac.id
}

Naskah diterima: 24 Januari 2021 | Disetujui: 30 April 2021 | Diterbitkan: 11 Mei 2021

\begin{abstract}
Parenting style greatly influences the success of a child. The purpose of this study was to determine the factors that influence the low learning motivation of students and to find out how parenting styles of students' parents at home so that it can affect children's learning motivation. This type of research is descriptive with a qualitative approach. The research subjects included students and homeroom teachers. The data collected in this study used interview and observation techniques. The data collected were analyzed using interactive analysis from miles and huberman which includes three, namely data reduction, data presentation and drawing conclusions or verification. The results showed that the parenting style very influential on students' learning motivation, parents who are busy but do not pay attention to the child's learning process have an impact on the child's lack of enthusiasm in learning, the parenting style adopted by both authoritarian and democratic parents has an effect on children's development and motivation in study.
\end{abstract}

Keywords: parenting, motivation to learn, parents

\begin{abstract}
Abstrak
Pola asuh yang dilakukan oleh orang tua sangat mempengaruhi kesuksesan seorang anak. Tujuan penelitian ini adalah untuk mengetahui faktor-faktor yang mempengaruhi rendahnya motivasi belajar siswa dan untuk mengetahui bagaimana pola asuh orang tua siswa-siswi di rumah sehingga dapat mempengaruhi motivasi belajar anak. Jenis penelitian ini adalah deksriptif dengan pendekaan kualitatif. Subjek penelitian meliputi siswa dan wali kelas. Teknik pengumpulan data yang digunakan dalam penelitian ini menggunakan tehnik wawancara dan observasi. Data yang dikumpulkan dianalisis menggunakan analisis interaktif dari Miles dan Huberman yang meliputi tiga tahap, yaitu reduksi data, sajian data, dan penarikan kesimpulan atau verifikasi. Hasil penelitian menunjukkan bahwa pola asuh orang tua sangat berpengaruh terhadap motivasi belajar siswa, orang tua yang sibuk tetapi tidak memperhatikan proses belajar anak berdampak terhadap kurang semangatnya anak dalam belajar, gaya pengasuhan yang dilakukan oleh orang tua baik otoriter maupun demokratis berpengaruh terhadap perkembanagan serta motivasi anak dalam belajar.
\end{abstract}

Kata kunci: pola asuh, motivasi belajar, orang tua 


\section{Pendahuluan}

Keluarga merupakan kumpulan terkecil dari masyarakat. Peran ayah dan ibu terhadap anakanaknya sangat diperlukan untuk keberhasilan dalam pendidikan (Arumsari,2017). Peran penting tersebut diantaranya adalah bimbingan, perhatian, dan kasih sayang. Choirul (dalam Faizal, 2015) berpendapat bahwa keluarga merupakan dunia anak yang pertama kali memberikan sumbangan mental dan fisik. Perlakuan orang tua terhadap anak berpengaruh dalam proses pertumbuhan dan perkembangan psikis, serta sosial pada diri anak. Cara terbaik yang dapat dilakukan orang tua dalam pendidikan anak adalah memberikan pola asuh yang terbaik. Mendidik anak di era 21 perlu usaha yang ekstra dibandingkan dengan zaman dulu. Hal tersebut dikarenakan perkembangan dunia digital telah memberikan kemudahan dalam segala proses pada lini kehidupan, di sisi lain kemudahan yang didapat oleh teknologi juga mampu menjadi jurang pemisah antara orang tua dan anak.

Anak akan mengalami proses pencarian jati diri ketika memasuki usia remaja, dalam proses pencarian jati diri ini seorang anak membutuhkan dukungan keluarga untuk menemukan identitas dirinya. Seperti pendapat (luyckx, 2016) bahwa seorang anak akan mampu membentuk dirinya dengan baik jika lingkungan keluarganya mendukung proses tersebut dengan pola asuh yang baik pula, meskipun masih banyak ditemukan pola asuh yang kurang tepat sehingga menghambat proses tumbuh kembang pola pikir anak. Oleh karena itu, orang tua membutuhkan lembaga yang mampu memberikan pendidikan moral yang baik terhadap siswa yakni sekolah. Dalam rangka pelaksanaan pendidikan nasional, peran keluarga sebagai lembaga pendidikan akan sangat penting sehingga motivasi belajar anak di lembaga pendidikan juga dipengaruhi oleh faktor perlakuan yang didapatkan saat di rumah. Hal ini berdasarkan amanat yang disampaikan oleh Direktur Pembinaan Pendidikan Keluarga Ditjen PAUD dan Dikmas tentang perlibatan keluarga dan masyarakat dalam pendidikan nasional yang memiliki tujuan untuk mewujudkan kerjasama dan keselarasan program pendidikan di sekolah, keluarga, dan masyarakat sebagai tri sentra pendidikan dalam membangun ekosistem pendidikan yang menumbuhkan karakter dan budaya berprestasi peserta didik. Menurut Gunarsa (dalam Rabiatul Adawiah, 2017) bahwa mengasuh anak merupakan sebuah metode seseorang untuk bertindak dalam suatu hubungan dengan anak-anak yang merupakan aktivitas keseharian. Resolusi PBB juga menyampaikan bahwa fungsi utama keluarga adalah sebagai sebuah kendaraan untuk mendidik, memelihara, serta meningkatkan semua kemampuan anak.

Penelitian tentang pengaruh pola asuh orang tua terhadap motivasi belajar siswa sudah banyak dikaji, seperti pada penelitian yang dilakukan oleh (Dinniar, 2017) di mana penelitiannya mengkaji tentang kurangnya motivasi orang tua terhadap proses belajar siswa. Hasil penelitiannya menunjukkan bahwa siswa kurang mendapatkan pengarahan untuk belajar di rumah, sehingga mempengaruhi prestasi anak. Tidak jauh berbeda dengan penelitian yang dilakukan oleh (Harianti, 2016) yang mengkaji tentang orang tua tidak bisa memahami dan memberikan waktu kepada anak untuk melakukan proses belajarnya. Dalam penelitian ini Rini Hartanti mengkaji studi kasus tentang siswa yang memiliki pekerjaan tambahan di luar jam sekolah untuk membantu orang tuanya bekerja, sehingga tidak ada waktu untuk belajar. Penelitian yang dilakukan oleh (Lumbantoruan \& Raharjo, 2019) tentang hubungan pola asuh anak dan konsep diri anak didik. Pada penelitian ini peneliti mengkaji tentang pengasuhan orang tua yang menggunakan pola asuh otoriter dan pesimis sehingga membuat anak tidak mempunyai keberanian dalam bersosial dan sangat mempengaruhi proses pendidikannya. 
Kajian terhadap penelitian sebelumnya sudah banyak memaparkan sebab-sebab kurangnya motivasi anak dalam proses pendidikan. Namun begitu pada penelitian yang telah dipaparkan sebelumnya belum mengkaji tentang pola asuh orang tua yang memiliki finansial cukup tetapi motivasi belajar anak masih rendah ketika belajar di sekolah. terdapat tiga faktor penting yang mempengaruhi prestasi belajar anak, salah satunya adalah faktor eksternal yang terdiri dari lingkungan sosial seperti pendidikan orang tua dan keadaan ekonomi orang tua (Muhibbin, 2010). Menurut penelitian yang dilakukan oleh (Shaleh, 2016) bahwa tinggi rendahnya prestasi belajar siswa ada hubungannya dengan tingkat penghasilan orang tua. Semakin tinggi tingkat penghasilan orang tua diharpakan mampu untuk memberikan perhatian dan kasih sayang yang lebih terhadap anaknya, sehingga dapat meningkatkan motivasi siswa untuk meningkatkan prestasi belajarnya.

Dari berbagai penelitian yang dipaparkan menunjukkan bahwa masih ada kesenjangan antara keadaan orang tua yang berpengahasilan tinggi dengan motivasi belajar siswa, sehingga penulis tertarik untuk melakukan penelitian tentang faktor yang mempengaruhi siswa dari keluarga yang memiliki finansial baik, tetapi tidak mampu menumbuhkan semangat belajar pada diri mereka. Kontribusi teoritis penelitian ini diharapkan dapat menjadi acuan bagi para orang tua tentang menumbuhkan pola asuh yang baik terhadap anak.

\section{Pola Asuh}

Pola asuh merupakan sesuatu yang sangat penting di dalam keluarga. Pola asuh yang baik didapat dari hubungan orang tua dan anak yang baik dan penuh dengan pendidikan karakter. Orang tua merupakan role model pada masa perkembanga anak, mereka selalu ingin melakukan atau meniru sesuatu yang mereka lihat dan mereka dengar dari lingkungannya (Rabiatul, 2017). Ada beberapa pandangan yang dikemukakan oleh para peneliti tentang pola asuh, seperti pola asuh yang didasarkan pada tata bahasa merupakan model atau sistem dalam menjaga atau mendidik seseorang sehingga menjadi manusia yang mandiri.

Poetranto (dalam Suarsiny \& Desi, 2013) menyatakan bahwa pola asuh merupakan sesuatu yang diterapkan oleh orang dewasa yaitu orang tua terhadap anak dalam waktu yang panjang dan anak dapat merasakan sisi positif maupun negatif dalam metode pengasuhannya. Peneliti menyimpulkan bahwa pola asuh merupakan proses pembelajaran atau penanaman sebuah karakter, sehingga menjadi sebuah kebudayaan dalam diri anak dan akan terus dilestarikan dalam kehidupan sehari-hari.

Ada beberapa tipe pembimbingan orang tua terhadap anak, menurut (Baumrind, 1991) terdapat tipe pola asuh yang dapat diterapkan oleh orang tua, yaitu tipe autoriatif, pola asuh otoriter, dan pola asuh permisif. Orang tua yang mempunyai sikap terbuka terhadap anak dan menghargai berbagai macam kedisplinan merupakan tipe pola asuh autoriatif, sedangkan pola asuh otoriter ditandai dengan berbagai macam aturan yang diberikan orang tua terhadap anak, orang tua tipe otoriter ini cenderung tidak memberikan kesempatan anak untuk berdiskusi dan mengemukakan pendapatnya, sehingga anak yang diasuh dalam lingkungan pengasuhan otoriter cenderung memiliki sifat penakut dan tidak bahagia. Pola asuh tipe ketiga ini merupakan pola asuh yang lebih memiliki kebebasan tanpa batas terhadap anak, hal ini mengakibatkan anak akan bertindak sesuka hatinya. Apabila anak mampu menggunakan kebebasan yang diberikan oleh orang tua dengan positif, maka 
anak dalam pengasuhan tipe permisif akan menjadi anak yang mandiri, kreatif, dan mempunyai inisiatif untuk mewujudkan keinginanya (Santosa \& Marheni, 2013).

\section{Motivasi Belajar Siswa}

Proses pembelajaran berlangsung dalam jangka waktu yang sangat lama dan sangat membutuhkan motivasi dalam usaha sadar untuk bisa menggerakkan, meningkatkan kemampuan dan daya belajar, serta tingkah laku sehingga bisa mempunyai dorongan dalam diri untuk mencapai suatu tujuan (Hamdu \& Agustina, 2011). Motivasi juga merupakan sebuah kekuatan yang timbul dalam diri seseorang sehingga berdampak pada kemauan dalam melaksanakan suatu kegiatan (Suprihatin,2015). Clayton Alderfer (dalam Nashar, 2004) memberikan pendapat bahwa motivasi belajar merupakan aktivitas seseorang yang memiliki kecendrungan untuk melakukan kreativitas belajar yang didorong keinginann kuat untuk mendapatkan hasil yang baik dari proses belajarnya. Motivasi juga dapat dikatakan sebagai sebuah proses internal yang memberikan pengaruh terhadap diri seseorang untuk mengaktifkan, menuntun, dan mempertahankan perilaku yang positif dari waktu kewaktu, apabila motivasi dimiliki oleh seorang siswa maka impian mereka terhadap hasil belajar akan lebih baik (Sjukur, 2013).

Pemuasan terhadap sebuah kebutuhan merupakan salah satu motif yang menggerakkan seseorang. Barelson dan Steiner memandang motivasi sebagai suatu rantai reaksi yang dimuai dari adanya kebutuhan, lalu timbul menjadi sebuah keinginan untuk mencapai tujuan, sehingga psikologis dalam diri akan mengarahkan perilaku kepada tujuan tersebut.(Irmalia, 2001).

Faktor-faktor lainnya yang mempengaruhi motivasi belajar pada sesorang adalah faktor internal dan eksternal. Faktor internal/instrinsik merupakan sesuatu yang timbul dalam diri seseoang seperti sebuah harapan, minat, cita-cita, dan aspek lain yang ada dalam diri seseorang. Sedangkan motivasi eksternal/ekstrinsik merupakan motivasi yang muncul karena adanya dorongan dari luar baik lingkungan belajar ataupun lingkungan keluarga. Hal ini dapat berupa ancaman yang akan menimbulkan rasa takut terhadap diri seseorang sehingga ia melakukannya dengan tujuan terhindar dari hukuman. Selain itu dapat juga berupa dorongan reward yang akan membuat ia mendapatkan hadiah jika melakukan sesuatu (Upoyo \& Sumarwati, 2011).

Dari beberapa pendapat di atas dapat disimpulkan bahwa motivasi merupakan sebuah keinginan yang besar dalam diri seseorang untuk melakukan sesuatu. Demikian pentingnya motivasi belajar yang harus dimiliki oleh anak agar mendapatkan keberhasilan dalam belajarnya. Pola asuh menjadi salah satu faktor ekstrinsik yang dapat mendorong anak agar memiliki motivasi yang timbul dalam dirinya, pola asuh tersebut dapat terindikasi dari kontrol terhadap anak dan komunikasi dengan anak. Dengan adanya pola asuh yang tepat dari orang tua, maka motivasi belajar anak akan semakin baik.

Penelitian yang dilakukan peneliti menggunakan pendekatan kualitatif yaitu jenis penelitian yang bertujuan untuk menganalisis fenomena, peristiwa, dan aktivitas sosial baik secara individual maupun kelompok (Sukamdinata, 2007). Teknik yang digunakan dalam penelitian ini adalah analisis deskriptif. Analisis deskriptif digunakan untuk menjelaskan pola asuh orang tua terhadap motivasi belajar siswa secara lebih mendalam. Untuk mengungkapkan data tersebut maka peneliti perlu melakukan pengamatan atau observasi dan berinteraksi secara langsung dengan partisipan yang meliputi siswa dan wali kelas. 
Subjek penelitian terdiri dari wali kelas dan sembilan orang siswa. Penelitian ini dilakukan di SMP Unggulan Aisyiyah Bantul. Teknik pengumpulan data pada penelitian ini menggunakan teknik wawancara semi terstruktur dan observasi. Sedangkan teknis analisis data menggunakan model analisis interaktif Huberman \& Miles (1884) (dalam Sapat et al., 2017) di mana terdapat tiga komponen penting dalam penggunaan model yang meliputi reduksi data, sajian data, dan penarikan kesimpulan.

\section{Dampak Kesibukan Orang Tua Mempengaruhi Motivasi Belajar Siswa}

Siswa SMP Unggulan Aisyiyah Bantul rata-rata tidak memiliki permasalahan pembiayaan pendidikan, kesibukan orang tua menjadi faktor yang mendominasi motivasi belajar responden. Hal itu terlihat dari wawancara yang dilakukan peneliti terhadap beberapa responden. Tidak hadirnya orang tua pada setiap pertemuan wali di sekolah dengan alasan pekerjaan yang tidak bisa ditinggalkan menjadi sebab kurangnya percaya diri pada anak. Kurangnya perhatian orang tua terhadap kepentingan anak pada aktivitas pendidikan membuat orang tua tidak memahami tumbuh kembang anak dalam proses belajar. Status pekerjaan orang tua juga dapat berpengaruh terhadap pertumbuhan dan perkembanagan yang dialami oleh anak. Heinrich (2014) menjelaskan bahwa orang tua yang memiliki kesibukan di luar rumah/pekerja menjadi hal penting untuk tetap membangun kebersamaan dan perhatian terhadap anak, sehingga pekerjaan orang tua bukan lagi menjadi faktor penghambat motivasi belajar anak. Handayani (2003) menjelaskan bahwa seorang ibu yang memiliki pekerjaan di luar ibu rumah tangga akan memiliki waktu kebersamaan yang kurang dengan si anak, sehingga banyak dari orang tua mengurangi waktu bekerjanya untuk menstimulasi pertumbuhan dan perkembangan anaknya (Haryati,2012). Hal serupa juga ditemukan dalam penelitian terhadap wali kelas, hasil penelitian yang diperoleh bahwa siswa-siswi yang mengalami kurangnya perhatian dari orang tua membuat mereka tidak bersemangat untuk melaksanakan proses pembelajaran. Hal tersebut karena tidak ada motivasi yang harus dibanggakan kepada orang tuanya yang kurang perhatian. Kesibukan orang tua juga disebabkan oleh beberapa tuntutan ekonomi yang harus dipenuhi dalam keluarga baik pemenuhan kebutuhan hidup, jenjang karir, maupun pendidikan anak.

Faktor kesibukan orang tua seharusnya tidak menjadi penyebab kurangnya perhatian dan pengasuhan maupun pendampingan untuk anak, sehingga anak tidak kehilangan peran orang tua. Pola asuh orang tua yang baik akan menghasilkan kepribadian yang baik pula dalam tumbuh kembang anak. Sebaliknya, jika pola asuh yang diterapkan dalam keluarga yang kurang memperdulikan kebutuhan anak akan menghasilkan pengaruh negatif terhadap anak tersebut. Sebagian responden mengatakan bahwa faktor di rumah sangat berpengaruh pada motivasi belajar anak ketika di sekolah, anak akan cenderung tidak peduli dengan pembelajaran karena membawa masalah dari rumah. Masalah-masalah itu di antaranya seperti orang tua yang suka emosi yang membuat kepribadian responden dari baik menjadi kurang baik, emosi yang tidak stabil, dan kurang menghargai guru disaat pembelajaran berlangsung. Ada sebagian responden yang mengatakan bahwa kesibukan orang tua membuat responden tidak bersemangat karena kurang memperhatikan belajarnya. Data yang serupa juga ditemukan saat peneliti melakukan observasi di sekolah. Faktor pola asuh orang tua dalam hal ini mengemukakan bahwa fasilitisas belajar yang diberikan sekolah maupun orang tua belum mampu meningkatkan motivasi belajar siswa jika tidak disatukan dengan pola asuh yang baik oleh orang tua dalam proses pembelajarannya. 
Dalam proses pembelajaran sangat diperlukan kepedulian orang tua untuk mendampingi anak belajar serta dapat memberikan asupan yang baik bagi psiksis anak, sehingga anak dapat melewati masa remaja dan masa belajarnya dengan baik. Anak-anak membutuhkan pola asuh yang baik dari orang tua karena hal tersebut sangat mempengaruhi perkembangan motorik kasar dan halus pada anak (Rati et al., 2014). Pola asuh yang baik dapat diterapkan oleh orang tua dengan bersikap merawat anak dengan baik, memberi kasih sayang, membimbing atau mengarahkan, serta memberikan nilainilai kebaikan terhadap anak (Pucangan, 2017). Rohner (dalam Wibowo, 2016) berpendapat bahwa pola asuh orang tua sangat mempengaruhi perilaku, emosi, kognitif, serta fungsi psikologis anak, baik orang tua yang menolak (rejection) maupun menerima (acceptance) anak tersebut.

Orang tua harus mampu membentuk karakter anak dengan baik. Karakter yang sangat penting untuk dimiliki oleh seorang anak pada tahap perkembangan adalah rasa percaya diri. Percaya diri yang dimiliki oleh seorang anak merupakan faktor internal yang berpengaruh terhadap proses belajar anak. Anak dengan rasa percaya diri akan menganggap bahwa dirinya mampu dan mempunyai kelebihan, sehingga anak akan memiliki semangat dan sifat optimis untuk meraih kesuksesan (Komaruddin \& Bashori, 2016).

\section{Gaya Pengasuhan Orang Tua Terhadap Motivasi Belajar Siswa}

Tabel 1. Rekapitulasi gaya pengasuhan orang tua

\begin{tabular}{|c|c|c|}
\hline Nama Siswa (Inisial) & Gaya Pengasuhan & Motivasi Belajar \\
\hline DAA & Otoriter & Sedang \\
\hline PGN & Demokratis & Tinggi \\
\hline RDK & Demokratis & Tinggi \\
\hline TGT & Otoriter & Rendah \\
\hline ASKMM & Otoriter & Rendah \\
\hline DFH & Otoriter & Rendah \\
\hline BAPP & Demokratis & Rendah \\
\hline ZB S & Demokratis & Sedang \\
\hline NUA & Demokratis & Tinggi \\
\hline F & Demokratis & Tinggi \\
\hline
\end{tabular}

Berdasarkana anlisis data yang telah dilakukan, peneliti dapat mendeskripsikan tentang beberapa bentuk gaya pengasuhan yang dilakukan oleh orang tua. Hal tersebut sangat berpengaruh terhadap motivasi belajar siswa. Pola asuh yanng otoriter akan cenderung membuat anak terganggu pada motivasi belajarnya, sehingga motivasi belajar anak menjadi tidak tinggi serta memiliki kecerdasan sosial yang kurang karena berbagai tekanan yang dirasakan oleh anak. Oleh karena itu, anak memiliki tingkat kepercayaan diri yang rendah dan cenderung bersikap agresif. Hasil penelitian ini sejalan dengan penelitian yang dikemukakan oleh Scochib (2000) (dalam Dewi \& Susilawati, 
2016)(Dewi \& Susilawati, 2016) bahwa orang tua yang memiliki sikap otoriter akan cenderung mendorong anak untuk bersikap agresif, hal ini dapat menghambat kemajuan anak dalam lingkup sosialnya. Pengasuhan otoriter yang diterapkan oleh orang tua menjadi bentuk konsekuensi yang harus diterima anak secara berlebihan. Gaya pengasuhan otoriter ini membuat anak selalu takut, cemas, dan tidak dapat mengungkapkan pendapatnya, sehingga anak memiliki dua sikap yang berbeda yakni sikap yang cenderung pendiam di sekolah dan tidak pernah mengungkapkan pendapat saat pembelajaran, serta sikap yang mengungkapkan kekesalannya kepada teman-temannya sehingga sering bersikap kasar.

Gaya pengasuhan yang memiliki ciri membatasi, menghukum, dan menganggap bahwa kepatuhan anak terhadap orang tua sangat penting akan membuat orang tua tersebut memberi desakaan kepada anaknya untuk selalu mengikuti aturan yang menjadi keputusan orang tua. Orang tua yang menerapkan pola asuh tersebut merupakan orang tua yang menginginkan anaknya sempurna sesuai dengan apa yang orang tua inginkan. Hal ini selaras dengan penelitian Utomo et al., (2021) bahwa orang tua yang otoriter selalu menunjukkan amarah yang berlebihan. Jika anak tidak sesuai dengan keinginan orang tuanya akan mengakibatkan kecenderungan untuk tidak bersikap hangat kepada anak.

Gaya pengasuhan demokratis yang diterapkan oleh orang tua di rumah sesuai dengan hasil wawancara yang peneliti lakukan terhadap responden, baik terhadap siswa ataupun wali kelas. Anak yang memiliki orang tua dengan pola pengasuhan demokratis cenderung memiliki motivasi belajar yang tinggi, hal tersebut dapat dibuktikan dengan nilai pekerjaan anak dan hasil observasi yang peneliti lakukan. Anak dengan gaya pengasuhan demokratis cenderung memiliki kepercayaan diri yang tinggi dan aktif di dalam mengikuti mata pelajaran, serta selalu berperilaku yang baik saat berada di lingkungan sekolah. Asumsi peneliti terhadap perilaku demokratis yang dilakukan oleh orang tua siswa merupakan gaya pengasuhan yang baik untuk pertumbuhan dan perkembangan siswa, hal tersebut karena anak diberikan kebebasan untuk mengeksplorasi kemampuan dengan batasan serta pengawasan yang baik dari orang tua, sehingga anak dengan gaya pengasuhan demokratis merasa sangat dipedulikan. Selain itu, oang tua dengan pengasuhan demokratis akan merasa angat dengat dengan dirinya dan sangat perduli terhadap proses pembelajaran sehingga responden merasa bahwa harus melakukan yang terbaik tanpa ada paksaan dalam diri, sehingga anak memilki kecerdasan emosional yang baik. Hal ini selaras dengan penelitian yang dilakukan oleh Septiani (2017) bahwa pola asuh demokratis sangat berpengaruh terhadap tumbuh kembang anak salah satunya adalah kecerdasan emosional. Dari hasil penelitian tersebut dapat dijelaskan bahwa kecerdasan emosionnal dapat berkembang apabila anak mengalami dukungan baik dari lingkungan keluarga yang baik.

\section{Kesimpulan}

Dalam proses pengasuhan antar orang tua yang satu dengan yang lainnya tidaklah sama sehingga perbedaan ini mengahasilkan perilaku yang berbeda pula terhadap perilaku anak. Anak akan termotivasi dalam proses pembelajaran apabila pola asuh orang tua juga baik di aktivitas sehari-hari maupun dalam pembimbingan belajar, sehingga anak akan merasa dirinya diperdulikan. Fasilitas belajar dari orang tua juga ikut berpengaruh, tetapi menjadi tidak berarti tanpa ada pendampingan 
yang baik dari orang tua. Gaya pengasuhan yang diterapkan oleh orang tua juga memiliki andil yang besar dalam motivasi belajar anak.

\section{Pernyataan}

Penulis mengucapkan terimakasih banyak terhadap pihak terkait dalam penelitian ini. Terimakasih terhadap Wali Kelas SMP Unggulan 'Aisyiyah Bantul, Wali Siswa SMP Unggulan 'Aisyiyah Bantul dan Santriwan/Santriwati SMP unggulan 'Aisyiyah Bantul yang bersedia membantu terlaksananya penelitian ini. Terhadap pengelola jurnal Qalamuna, penulis menyampaikan terima kasih banyak atas kesempatan submite jurnal yang masih banyak kekurangan.

\section{Referensi}

Arumsari, R. (2017). Perbedaan Motivasi Belajar Antara Siswa Yang Berasal Dari Jawa Dan Dari Papua Di Sman 1 Kediri. Simki-Pedagogia, 01(08), 1-13.

Baumrind, D. (1991). The Influence of Parenting Style on Adolescent Competence and Substance Use. Journal of Early Adolescence, 11(1), 56-95.

Dewi, N. P. A. R., \& Susilawati, L. K. P. A. (2016). Hubungan Antara Kecenderungan Pola Asuh Otoriter (Authoritarian Parenting Style) dengan Gejala Perilaku Agresif Pada Remaja. Jurnal Psikologi Udayana, 3(1), 108-116. https://doi.org/10.24843/jpu.2016.v03.i01.p11

Dinniar, ajeng. (2017). Strategi Guru Dalam Memotivasi Belajar Siswa Program Studi Pendidikan Guru Madrasah Ibtidaiyah Fakultas Tarbiyah Dan Ilmu Keguruan Institut Agama Islam Negeri ( Iain) Purwokerto.

Faizal, M. (2015). Membangun Indonesia Yang Kuat Dari Keluarga "Indonesian Strong From Home.” Jurnal Pendidikan Guru Sekolah Dasar, I, 1115-1135.

Hamdu, G., \& Agustina, L. (2011). Pengaruh Motivasi Belajar Siswa Terhadap Prestasi I Belajar IPA di Sekolah Dasar (Studi Kasus terhadap Siswa Kelas IV SDN Tarumanagara Kecamatan Tawang Kota Tasikmalaya). Jurnal Penelitian Pendidikan, 12(1), 81-86.

Harianti, R. (2016). Pola Asuh Orangtua Dan Lingkungan Pembelajaran Terhadap Motivasi Belajar Siswa. Curricula, 2(2), 20-30. https://doi.org/10.22216/jcc.v2i2.983

Irmalia, A. S. (2001). Motivasi Belajar Dan Faktor-Faktor Yang Berpengaruh: Sebuah Kajian Pada Interaksi Pembelajaran Mahasiswa Irmalia Susi Anggraini *. Jurnal Mahasiswa, 1, 100-109.

Komaruddin, H., \& Bashori, K. (2016). Psikologi Sosial. Erlangga.

Lumbantoruan, R. S., \& Raharjo, S. T. (2019). Pola Asuh Orangtua Dan Konsep Diri Anak Didik Lpka Bandung. Focus: Jurnal Pekerjaan Sosial, $2(1), \quad 137$. https://doi.org/10.24198/focus.v2i1.23130

luyckx, M. (2016). Intergenerational Associations Linking Identity Styles and Processes in Adolescents and Their Parents (pp. 67-83).

Muhibbin, S. (2010). Psikologi pendidikan dengan pendekatan baru. PT Remaja Rosdakarya. 
Nashar. (2004). Peranan Motivasi dan Kemampuan Awal dalam Kegiatan Pembelajaran (Delia Press (ed.)).

Pucangan, K. dkk. (2017). Hubungan antara konsep diri dan pola asuh orang tua terhadap hasil belajar IPA siswa kela V SD di desa Selat. Jurnal Mimbar PGSD Universitas Pendidikan Ganesha, 5(2), 1-10.

Rabiatul, A. (2017). Pola Asuh Orang Tua dan Implikasinya Terhadap Pendidikan Anak. Jurnal Pendidikan Kewarganegaraan, 7(1), 33-48.

Rati, N. W., Antari, Ma., \& Budiarnawan, A. (2014). Hubungan Antara Konsep Diri Dan Pola Asuh Orang Tua Terhadap Hasil Belajar Ipa Siswa Kelas V Sd Di Desa Selat. Jurnal Mimbar Pgsd Universitas Ganesha, 2(2-3).

Santosa, A. W. U., \& Marheni, A. (2013). Perbedaan Kemandirian Berdasarkan Tipe Pola Asuh Orang Tua pada Siswa SMP Negeri di Denpasar Ayu Winda Utami Santosa dan Adijanti Marheni. Jurnal Psikologi Udayana, 1(1), 54-62.

Septiani, W. (2017). Hubungan Pola Asuh Demokratis dan Konsep Diri Terhadap Perkembangan Kecerdasan Emosional. Indonesian Journal of Guidance and Counseling: Theory and Application, 6(3), 22-26.

Shaleh, M. (2016). Pengaruh Motivasi, Faktor Keluarga, Lingkungan Kampus Dan Aktif Berorganisasi Terhadap Prestasi Akademik. Phenomenon : Jurnal Pendidikan MIPA, 4(2), 109. https://doi.org/10.21580/phen.2014.4.2.122

Sjukur, S. B. (2013). Pengaruh blended learning terhadap motivasi belajar dan hasil belajar siswa di tingkat SMK. Jurnal Pendidikan Vokasi, 2(3), 368-378. https://doi.org/10.21831/jpv.v2i3.1043

Suarsiny, \& Desi. (2013). Pola Asuh Orang Tua. Artikel\%0A(online)(http;//desysuar.blogspot\%0A.com,

SUkamdinata. (2007). Metodologi Penelitian Tindakan. PT Remaja Rosdakarya.

Suprihatin, S. (2015). Upaya Guru Dalam Meningkatkan Motivasi Belajar Siswa. PROMOSI (Jurnal Pendidikan Ekonomi), 3(1), 73-82. https://doi.org/10.24127/ja.v3i1.144

Upoyo, A., \& Sumarwati, M. (2011). Analisis faktor- Faktor Yang Mempengaruhi Motivasi Mahasiswa Profesi Ners Jurusan Keperawatan Unsoed Purwokerto. Soedirman Journal of Nursing, 6(2), 81-87.

Utomo, E., Fajar, N. A., \& Misnaniarti. (2021). Pola Asuh Orang Tua Otoriter, Demokratis, Permisif Dengan Perilaku Merokok Pada Siswa Smp Di Kota Palembang. 6, 19-35.

Wibowo, A. (2016). Hubungan Lingkungan Kampus, Pola Asuh Orang Tua dan Motivasi Berprstasi Mahasiswa Fakultas Ekonomi Universitas Negeri Jakarta. 16(September). 
Pola Asuh Orang Tua Terhadap Motivasi Belajar Siswa SMP Unggulan 'Aisyiyah Bantul Saibah, Wantini 